\title{
Insulin signaling, inflammation, and lipolysis in subcutaneous adipose tissue of transition dairy cows either overfed energy during the prepartum period or fed a controlled-energy diet
}

\author{
S. Mann, ${ }^{*}$ D. V. Nydam, ${ }^{*}$ A. Abuelo,$\dagger^{1}$ F. A. Leal Yepes, $\ddagger$ T. R. Overton, $\ddagger$ and J. J. Wakshlag $\S^{2}$ \\ *Department of Population Medicine and Diagnostic Sciences, Cornell College of Veterinary Medicine, Ithaca, NY 14853 \\ †Department of Animal Pathology, College of Veterinary Medicine, Universidade de Santiago de Compostela, Lugo, 27002 Spain \\ fDepartment of Animal Science, and \\ $\S$ Department of Clinical Sciences, Cornell College of Veterinary Medicine, Ithaca, NY 14853
}

\section{ABSTRACT}

Adipose tissue mobilization is a hallmark of the transition period in dairy cows. Cows overfed energy during the dry period have higher concentrations of nonesterified fatty acids (NEFA) and $\beta$-hydroxybutyrate (BHB) compared with cows fed a controlled-energy diet prepartum. The reason for an increase in blood NEFA concentrations at the level of adipose tissue in cows overfed energy has not been fully elucidated. One hypothesis is that cows with high BHB concentrations suffer from adipose tissue-specific insulin resistance, leading to higher rates of adipose tissue mobilization in the postpartum period. To test this hypothesis, subcutaneous adipose tissue biopsies of cows overfed energy in excess of predicted requirements by $50 \%$ in the dry period, and that had high concentrations of blood BHB postpartum (group $\mathrm{H} ; \mathrm{n}=12$ ), were used. Findings were compared with results of biopsies from cows fed a controlled-energy diet and with low BHB concentrations postpartum (group $\mathrm{C} ; \mathrm{n}=12$ ) to create the biggest contrast in BHB concentrations. Subcutaneous adipose tissue biopsies were obtained before and $60 \mathrm{~min}$ after an intravenous glucose challenge $(0.25 \mathrm{~g} /$ $\mathrm{kg}$ of glucose) at 28 and $10 \mathrm{~d}$ before expected calving as well as on d 4 and 21 postpartum. Phosphorylation of protein kinase B, extracellular signal-regulated kinase, and hormone-sensitive lipase was determined before and after glucose infusion by Western blot. Western blot was also used to assess the baseline protein abundance of peroxisome proliferator-activated receptor gamma and insulin receptor $\beta$-subunit. In addition, gene ex-

\footnotetext{
Received January 31, 2016.

Accepted April 9, 2016.

${ }^{1}$ Present address: Graham Centre for Agricultural Innovation (Charles Sturt University and NSW Department of Primary Industries), School of Animal and Veterinary Sciences, Wagga Wagga, NSW 2678, Australia.

${ }^{2}$ Corresponding author: jw37@cornell.edu
}

pression of fatty acid synthase, adiponectin, monocyte chemoattractant protein 1 , and tumor necrosis factor $\alpha$ was determined by real-time quantitative reversetranscription PCR. Backfat thickness was determined in the thurl area by ultrasonography. Cows in group $\mathrm{H}$ showed a greater degree of lipogenesis prepartum, but no differences were found in lipolytic enzyme activity postpartum compared with cows in group C. Baseline plasma insulin concentrations were decreased and serum NEFA concentrations increased postpartum in group $\mathrm{H}$. Insulin signaling through protein kinase $\mathrm{B}$, quantity of insulin receptor, markers of inflammation, and peroxisome proliferator-activated receptor gamma in adipose tissue were not different between the groups, but expression of adiponectin was increased in adipose tissue of cows in group $\mathrm{H}$ during the immediate peripartum period. In conclusion, differences in serum concentrations of NEFA between cows overfed energy prepartum and high blood concentrations of BHB are likely due to greater negative energy balance postpartum reflected in lower circulating concentrations of glucose and insulin and an increase in the total amount of mobilized adipose tissue mass rather than due to changes in adipose tissue insulin signaling.

Key words: adipose, insulin, transition, energy

\section{INTRODUCTION}

The transition period in dairy cattle is characterized by changes in DMI and energy balance that affect adipose tissue metabolism as well as the rate of adipose tissue synthesis and mobilization. Mobilization of adipose tissue, which is reflected by the rise of serum concentration of nonesterified fatty acids (NEFA) in the peripartum period and especially during the first weeks after calving, is part of the physiological process of homeorhetic adaptation to lactation (Bauman and Currie, 1980; Bell, 1995). Epidemiological data provide evidence that an excessive increase in circulating NEFA 
concentration predisposes cows to negative health events, loss of reproductive success and milk production (Ospina et al., 2010; Garverick et al., 2013; McArt et al., 2013). High concentrations of blood NEFA also contribute to increased oxidative stress and dysfunctional inflammatory response during the postpartum period (Sordillo and Raphael, 2013) as well as development of fatty liver (Bobe et al., 2004).

In several studies, overfeeding cows energy during the dry period was associated with a higher concentration of circulating NEFA and BHB in the postpartum period compared with cows fed a controlled or restricted energy diet prepartum (Janovick et al., 2011; Khan et al., 2014; Mann et al., 2015). The underlying mechanism of this increase in NEFA concentration and ketogenesis is not fully understood because a difference in DMI is often absent postpartum (Rabelo et al., 2003; Mann et al., 2015). An increase in serum NEFA concentration can be due to an increase in lipolysis, a decrease in the re-esterification rate after release of NEFA from adipose stores, or a decrease in uptake of circulating NEFA (Bell, 1995). Both lipolysis and lipogenesis are influenced by circulating insulin concentrations as well as by the responsiveness and sensitivity of the adipose tissue to insulin (De Koster and Opsomer, 2013). Recent evidence suggests that cows overfed during the dry period have lower circulating concentrations of insulin in the immediate postpartum period (Janovick et al., 2011; Mann et al., 2016), which may directly affect adipose tissue lipolysis because of a decrease in insulin's direct and indirect anti-lipolytic effect (Corl et al., 2006; Frühbeck et al., 2014). However, a difference in resting concentrations of insulin postpartum between groups fed different dietary planes of energy prepartum was not observed in other similarly conducted studies (Dann et al., 2006; Douglas et al., 2006). Prepartum overfeeding was associated with increased plasma glucose (Mann et al., 2016) or insulin (Douglas et al., 2006) concentration prepartum, or an increase of both (Holtenius et al., 2003; Douglas et al., 2006; Janovick et al., 2011) in several recent studies. Excess intake of energy during the dry period may thus affect prepartal insulin secretion, interfere with adipose tissue signaling, and lead to a potential carry-over effect into lactation (Ji et al., 2012; Selim et al., 2015), predisposing cows to excessive mobilization of adipose tissue and an increase in ketogenesis postpartum.

Adipokines, such as adiponectin and tumor necrosis factor $\alpha(\mathbf{T N F} \boldsymbol{\alpha})$, and increased adipose tissue inflammation have been implicated as mediators in the development of insulin resistance during pregnancy in human medicine (Barbour et al., 2007). Clear evidence for a potential effect of dry period energy level and excessive body condition at calving on adipose tissue inflammation and immune cell infiltration in dairy cows is still lacking (Bradford et al., 2015).

Our objective was to investigate peripartal adipose tissue insulin signaling by measuring the activity of protein kinase B (AKT) and extracellular signalregulated kinase (ERK), as well as the activity of hormone-sensitive lipase (HSL) before and after a glucose challenge-induced endogenous insulin response in cows fed a high-energy dry period diet with high blood concentrations of BHB postpartum compared with cows fed a controlled-energy dry period diet and with low concentrations of BHB postpartum. Furthermore, gene expression of fatty acid synthase $(F A S N)$, adiponectin $(A D I P O Q), T N F \alpha$, and monocyte-chemoattractant protein 1 ( $M C P 1 / C C L 2)$, as well as protein abundance of insulin receptor $\beta$-subunit (INSR) and peroxisome proliferator-activated receptor gamma (PPAR $\gamma)$, was determined.

\section{MATERIALS AND METHODS}

\section{Animals, Feeding, and Management}

A detailed description of study animals, diets, milk and ECM production, and feed analysis as well as energy balance was described previously (Mann et al., 2015). In brief, animals entering second or greater parity were either fed a TMR formulated to meet, but not greatly exceed, energy requirements at predicted ad libitum intake (group $\mathbf{C}, \mathrm{n}=28$ ), or received a TMR formulated to supply $150 \%$ of energy requirements (group $\mathbf{H}, \mathrm{n}=28$ ) beginning at dry-off approximately $57 \mathrm{~d}$ before expected parturition. All animals were fed the same fresh cow diet (F). After analysis of feed composite samples with wet chemistry analysis (Dairy One Cooperative Inc., Ithaca, NY), estimation of energy balance and MP supply as a percentage of predicted requirements was carried out with the Cornell Net Carbohydrate and Protein System software (CNCPS; Cornell University, version 6.1). Analyzed diet composition, weekly weight, and DMI averages were entered, as well as days carried calf for prepartum estimates, and weekly averages of milk yield as well as milk fat, protein, and lactose concentration for postpartum estimates. The BCS was determined at enrollment and weekly throughout the study based on a 0- to 5-point scale as described by Edmonson et al. (1989). Animals for this study were specifically selected from the larger study population described in Mann et al. (2015) based on the concentration of BHB over time during the first 3 wk postpartum. To achieve this, area under the curve was based on 3 weekly BHB concentrations during the 
first 3 wk postpartum (9 samples total), which were determined in whole blood using a handheld meter (Precision Xtra meter, Abbott Diabetes Care Inc., Alameda, CA). The calculation was carried out following the method described by Cardoso et al. (2011) using SAS v. 9.3 (SAS Institute Inc., Cary, NC). Samples of animals with the highest total area under the curve of BHB concentration in group $\mathrm{H}(\mathrm{n}=12)$ and those with the lowest area under the curve in group $\mathrm{C}(\mathrm{n}=$ 12) were selected for this study to achieve the largest contrast in BHB concentrations. In each of the selected groups $\mathrm{C}$ and $\mathrm{H}, 7$ and 5 animals were entering second and third lactation, respectively.

\section{Ultrasound Measurements}

At enrollment (57 d before expected parturition), on d 28 and 10 before expected parturition, and d 4, 21, and 42 after parturition, ultrasonographic measurements of the subcutaneous fat thickness in the thurl area were carried out using a modification of the method previously described by Schröder and Staufenbiel (2006) and Joshi and Herdt (2009). In brief, fat thickness was measured on the right side of the animal as the distance between the skin and the profound fascia above the gluteus medius muscle on a line between the tuber coxae and tuber ischia, approximately $10 \mathrm{~cm}$ cranial to the latter. Backfat thickness (BFT) was expressed excluding the measurement of the skin and values given are therefore actual fat thickness. The hair in the area corresponding to the exact placement of the ultrasound probe as determined during the first examination was clipped to the size of the probe to ensure repeatable probe placement. The skin surface was brushed and $70 \%$ alcohol (VetOne, Boise, ID) was applied as a coupling agent before measurements were performed using the IBEX Pro portable ultrasound (E.I. Medical Imaging, Loveland, $\mathrm{CO}$ ) with a $8.5-\mathrm{MHz}$ linear array transducer. Each measurement was performed in triplicate, avoiding pressure as to not compress the underlying tissue, and the average of the 3 measurements was used for analysis.

\section{Blood Samples}

Venous blood samples were taken at the time of biopsy according to the methods previously described (Mann et al., 2016). In brief, 2 samples were taken from a jugular catheter $10 \mathrm{~min}$ apart, centrifuged within 30 min, and aliquots of plasma and serum stored at $-20^{\circ} \mathrm{C}$ until analysis for serum NEFA [HR Series NEFA-HR (2), Wako Life Sciences, Mountain View, CA] and plasma insulin (PI-12K Porcine Insulin RIA, Millipore
Corp., Billerica, MA) and glucose concentrations (Sigma-Aldrich, St. Louis, MO) as well as plasma glucose. Concentration of BHB in whole blood was determined cow-side using a Precision Xtra meter (Abbott Diabetes Care Inc.).

\section{Adipose Tissue Samples}

Biopsies of the subcutaneous adipose tissue were taken 28 and $10 \mathrm{~d}$ before expected parturition and 4 and $21 \mathrm{~d}$ after calving, immediately before and $60 \mathrm{~min}$ after rapid intravenous infusion of glucose at a dose of $0.25 \mathrm{~g} / \mathrm{kg}$ of BW (Mann et al., 2016). Samples were taken from the deepest point of the paralumbar fossa approximately 15 to $25 \mathrm{~cm}$ behind the last rib and 10 to $30 \mathrm{~cm}$ below the lumbar transverse processes. The biopsy sites were prepared by clipping the hair in the paralumbar fossa and scrubbing the skin with iodine soap (Pivodine Scrub 7.5\% Iodine, VetOne) and water. The area was rinsed with water and dried. The biopsy site was then aseptically prepared with iodine scrub and $70 \%$ alcohol (VetOne) before local anesthesia with $10 \mathrm{~mL}$ of a $2 \%$ lidocaine solution (lidocaine $2 \% \mathrm{HCl}$, VetOne) was performed following the pattern of an inverted L-block at a distance of at least $10 \mathrm{~cm}$ from the biopsy site. The surgical area was again scrubbed by alternating iodine scrub and alcohol as described above. A vertical skin incision of approximately 3 to $5 \mathrm{~cm}$ length was made and 2 to $4 \mathrm{~g}$ of the subcutaneous adipose layer was removed with sterile forceps and scalpel. Tissue samples were immediately snap frozen by immersion in liquid nitrogen in 2-mL cryovials (Nalgene, VWR, Radnor, PA) containing $500 \mu \mathrm{L}$ of RNA buffer solution (RNA later, Qiagen, Hilden, Germany) for later extraction of mRNA, or in the same cryovials without addition of buffer for immunoblotting.

\section{Preparation of $m R N A$ and Real-Time Quantitative Reverse-Transcription PCR}

Approximately $100 \mathrm{mg}$ of frozen adipose tissue from each sample were transferred to $500 \mu \mathrm{L}$ of ice-cold Trizol reagent (Life Technologies, Thermo Fisher Scientific, Waltham, MA), placed in the pre-chilled adapter of a tissue disruptor (TissueLyser LT, Qiagen, Hilden, Germany), and homogenized at maximum oscillation for 3 min with sterile 5 -mm stainless steel beads. Total RNA was extracted and treated in-column with DNase I (Direct-Zol RNA MiniPrep, Zymo Research, Irvine, CA). The optical density 260:280 ratio was measured with a spectrophotometer (NanoVue Plus, GE Healthcare, Life Sciences, Little Chalfont, UK) for quality control of integrity of RNA. For cDNA synthesis on the same day, up 
to $500 \mathrm{ng}$ of RNA was reverse-transcribed (SuperScript III First-Strand Synthesis SuperMix, Life Technologies, Thermo Fisher Scientific) and stored at $-20^{\circ} \mathrm{C}$ until analysis. Eukaryotic translation initiation factor $3 \mathrm{~K}$ (EIF3K) was chosen as the housekeeping control gene as recommended recently (Bonnet et al., 2013). Bovinespecific primer probe sets with exon spanning probes were purchased for the control gene and all genes of interest (EIF3K:Bt03226565, FASN:Bt03210491, CCL2/ MCP-1:Bt03212322, TNF $\alpha$ :Bt03259156; TaqMan Gene Expression Assays, Applied Biosystems, Thermo Fisher Scientific) except for adiponectin $(A D I P O Q)$ where an exon spanning primer probe set was not available (Bt03292341; TaqMan Gene Expression Assays, Applied Biosystems, Thermo Fisher Scientific). Real-time quantitative reverse-transcription PCR was performed using a 2 -fold dilution of cDNA at $10 \%$ of the final reaction volume, and each sample was analyzed in triplicate using a StepOne Plus system and $2 \times$ master mix (TaqMan Gene Expression Master Mix, Applied Biosystems, Thermo Fisher Scientific). The PCR protocol consisted of denaturation at $95^{\circ} \mathrm{C}$ for $10 \mathrm{~min}$, followed by 40 cycles of $95^{\circ} \mathrm{C}$ for $15 \mathrm{~s}$ (denaturation) and $1 \mathrm{~min}$ at $60^{\circ} \mathrm{C}$ (annealing and extension). For the calibration reference sample, aliquots of cDNA obtained from adipose tissue of a healthy cow at $28 \mathrm{~d}$ before expected parturition was used on every plate. Results were analyzed using the comparative quantification algorithmsstandard curve method $\left(\Delta \Delta \mathrm{C}_{\mathrm{t}}\right.$ method, v. 2.3, StepOne Software, Applied Biosystems). Results were expressed as relative quantity $\left(\mathbf{R Q}=2^{-\Delta \Delta \mathrm{Ct}}\right)$.

\section{Protein Extraction and Immunoblotting}

Approximately $100 \mathrm{mg}$ of frozen adipose tissue were homogenized with a tissue homogenizer (VDI 12, VWR) for approximately $60 \mathrm{~s}$ in $500 \mu \mathrm{L}$ of ice-cold RIPA lysis buffer containing $150 \mathrm{~m} M$ sodium chloride, $1 \%$ Triton $\mathrm{X}, 0.5 \%$ sodium deoxycholate, $0.1 \%$ sodium dodecyl sulfate, $50 \mathrm{~m} M$ Tris, and $1 \mathrm{~m} M$ phenylmethane sulfonyl fluoride with the addition of a phosphatase and protease inhibitor cocktail (Halt, Thermo Fisher Scientific), sonicated (550 Sonic Dismembranator, Thermo Fisher Scientific) for $6 \mathrm{~s}$, and kept on ice for $20 \mathrm{~min}$ before centrifugation at $14,000 \times g$ and $4^{\circ} \mathrm{C}$ for $15 \mathrm{~min}$. The fat layer was removed and the aqueous portion transferred. Then the protein concentration was determined by use of the Bradford technique (Bradford, 1976) using a commercially available reagent (Coomassie Protein Assay, Thermo Scientific, Rockford, IL). Lysates were adjusted to a protein concentration of $4 \mu \mathrm{g} / \mu \mathrm{L}$ and Western blot analysis was performed with $8 \%$ TrisGlycine SDS-polyacrylamide gels with loading amounts of $40 \mu \mathrm{g}$ of protein per well.
On each gel, a control sample obtained from a healthy cow at d 28 before expected parturition was loaded and results standardized to the densitometry results for the control sample to minimize variability in the results between gels. After wet transfer on ice to PVDF membrane (Immobilon-P, EMD Millipore, Billerica, MA) for $2 \mathrm{~h}$ at constant amperage (500 mA), membranes were blocked in 5\% nonfat milk for $1 \mathrm{~h}$. Membranes were incubated with primary antibodies to phosphorylated (p)ERK (Thr202/Tyr204), AKT, pAKT (Ser473), HSL, pHSL (Ser563), pHSL (Ser660), PPAR $\gamma$, and the $\beta$-subunit of the insulin receptor (Cell Signaling Technology, Danvers, MA), and to pan-ERK (BD Biosciences, Franklin Lakes, NJ) overnight at $4^{\circ} \mathrm{C}$. For antibodies without documented cross-reactivity with the bovine species, epitope homology was $100 \%$ except for HSL, pHSL (Ser563), and pHSL (Ser660), for which predicted homology was 89, 92, and 92\%, respectively. Use of these antibodies for HSL, pHSL (Ser563), and pHSL (Ser660) in bovine tissues was previously described (Elkins and Spurlock, 2009; Locher et al., 2011). All primary antibodies were diluted 1:1,000 in TBST, except for pHSL (Ser563) and pHSL (Ser660), which were diluted 1:2,000. After incubation with primary antibodies, membranes were washed 3 times with TBST and incubated for $1 \mathrm{~h}$ at room temperature with the appropriate 1:2,000 dilution of antirabbit or anti-mouse HRP-linked secondary antibodies (Cell Signaling Technology). Blots were again washed 3 times in TBST, exposed to enhanced chemiluminescent substrate (Clarity Western ECL Substrate, Bio-Rad, Hercules, CA), and imaged sequentially at 10, 20, 30, 50 , and $60 \mathrm{~s}$ intervals (BioSpectrum Imaging System, UVP, Upland, CA). Densitometry was performed using VisionWorks software (VisionWorks LS software, v. 8.1.2, UVP).

\section{Statistical Methods}

Repeated ultrasonographic measurements of BFT, EBAL estimates, DMI, milk and ECM yield, baseline gene expression and protein measurements before glucose infusion, as well as the change of protein phosphorylation of AKT, ERK, and HSL after glucose infusion, were analyzed using repeated measures ANOVA (Proc MIXED, SAS, v. 9.3, SAS Institute Inc.) with the fixed effects of group and time, and including a group $\times$ time interaction, actual sampling day at time point -28 was included in the model as a covariate. Five covariance structures were tested (unstructured, autoregressive 1, variance components, compound symmetry, and Toeplitz), and the one resulting in the lowest Akaike information criterion was chosen. The degrees of freedom were approximated with the Kenward-Roger method. 
Model assumptions were assessed by evaluation of homoscedasticity and normality of residuals. To satisfy this assumption, gene expression data and immunoblot densitometry data were natural log-transformed, and resulting least squares means estimates were subsequently back transformed and presented as the geometric mean and 95\% CI. Differences between BCS and BW, as well as the concentrations of NEFA, BHB, glucose, and insulin in blood samples and measurements obtained during intravenous glucose tolerance test (IVGTT), were analyzed by one-way ANOVA using the Proc MIXED in SAS. Differences in the proportion of animals with increase in phosphorylation of AKT postpartum was analyzed using Fisher's exact test. The association of AKT phosphorylation and resting insulin concentrations was assessed by Spearman correlation. Graphs were created with GraphPad Prism (v. 6.04, La Jolla, $\mathrm{CA}$ ). All results are presented as mean or geometric mean and $95 \%$ CI unless otherwise stated. All $P$-values given are those controlled for multiple comparisons with Tukey's honestly significant difference test.

\section{RESULTS}

\section{Energy Balance, Blood Concentration of Analytes, and BFT}

Energy balance in percentage of predicted requirements for wk 1 to 7 prepartum and wk 1 to 6 postpartum as well as milk production in the first 6 wk after calving is depicted in Figure 1. The energy density of the diets as estimated with CNCPS (v.6.1) was $1.98,2.23$, and 2.24 Mcal of $\mathrm{ME} / \mathrm{kg}$ of DM for the $\mathrm{C}, \mathrm{H}$, and $\mathrm{F}$ diets, respectively (Mann et al., 2015). As intended, prepartum energy balance was higher at every time point in group $\mathrm{H}$ [wk 1 to 7 prepartum: 157 (150-164) \%] compared with group C [109 (102-116) $\%, P<0.0001]$. Energy balance was lower in group $\mathrm{H}$ postpartum [71 (67-75) \%] compared with group C [76 (73-80) \%,P =0.05]. No differences were observed in average milk production during the first $6 \mathrm{wk}$ of lactation [group C: $45.2(41.4-48.1) \mathrm{kg} / \mathrm{d}$, group H 46.6 $(43.5-50.0) \mathrm{kg} / \mathrm{d}, P=0.60]$. By design, the area under the curve for BHB in the first 21 DIM was different for the selected cows and approximately twice as high in group $\mathrm{H}$ compared with group $\mathrm{C}$ [H: 22.6 (17.2-28.0) $\mathrm{mmol} / \mathrm{L}$; C $10.4(5.0-15.7) \mathrm{mmol} / \mathrm{L}, P=0.0003]$.

The actual average biopsy sampling day relative to calving was $-26.6(25.2$ to -27.9$),-7.5$ ( -6.0 to -9.0$)$, $+5.1(+4.6$ to +5.6$)$, and $+21.2(+20.7$ to +21.6$)$ d. Resting blood concentrations of glucose, insulin, NEFA, and BHB at the time of biopsy are listed in Table 1. No prepartum differences were observed in concentrations of NEFA, insulin, and BHB $(P>0.22)$, but glucose concentrations were higher in group $\mathrm{H}$ at both prepartum time points ( $P=0.05$ and 0.07 , respectively). Group differences were observed for all 4 analytes on d 4 and 21 postpartum with higher concentrations of NEFA and BHB, as well as lower concentrations of insulin and glucose in group $\mathrm{H}$ compared with group C.

Average BCS at enrollment was 3.04 (2.90-3.19) and $3.10(2.90-3.25)$ in group $\mathrm{C}$ and $\mathrm{H}$, respectively $(P=$ $0.53)$. Average BW at enrollment was $666(620-711)$ and $670(626-716) \mathrm{kg}$ in group $\mathrm{C}$ and $\mathrm{H}$, respectively $(P=0.87)$. Cows in group $\mathrm{C}$ gained on average 73.5 (59.5-87.5) kg, whereas cows in group $\mathrm{H}$ gained 93.9 (79.9-107.9) $\mathrm{kg}$ of BW during the dry period $(P=$ $0.04)$. Average weight loss was $24.3(5.9-42.5)$ and 40.1 (21.9-58.3) $\mathrm{kg}$ in group $\mathrm{C}$ and $\mathrm{H}$, respectively $(P=$ 0.21 ). Results for measurements of BFT and BW are depicted in Figure 2. An interaction between group and time $(P=0.04)$ existed in repeated measures analysis of BFT with a more rapid increase in group $\mathrm{H}$ until the time of calving and a more rapid decrease after calving whereas measurements at dry-off and $42 \mathrm{~d}$ postpartum were not different (Figure 2).

\section{Adipose Tissue Gene Expression}

The average ratio of absorbance $(260 / 280 \mathrm{~nm})$ of the RNA samples was $2.00(1.98-2.02)$. Figure 3 shows the gene expression of FASN, ADIPOQ, CCL2, and $T N F \alpha$ at 28 and $10 \mathrm{~d}$ prepartum, as well as 4 and 21 d postpartum. We found a treatment group difference for relative expression of FASN $(P=0.001)$ with the largest difference on d 10 prepartum [group $\mathrm{C}$ : $\mathrm{RQ}=$ $0.05(0.02-0.10)$, group $\mathrm{H}: \mathrm{RQ}=0.79(0.35-1.78), P$ $=0.003$. Expression over time was different in both postpartum samples compared with prepartum samples $(P<0.05)$ such that in both groups expression dropped to low values postpartum (RQ $<0.01)$. An interaction was noted for gene expression of ADIPOQ $(P=$ 0.04) with a lower expression in group $C$ compared with group $\mathrm{H}$ on d 10 prepartum [RQ: 1.7 (0.8-2.6) vs. $3.7(2.8-4.6)$ ], as well as d 4 [RQ: $2.3(1.4-3.3)$ vs. 4.2 (3.3-5.1)] and d 21 [RQ: $1.3(0.3-2.2)$ vs. $3.1(2.2-4.0)]$ postpartum. The expression of $C C L 2 / M C P 1$ and $T N F \alpha$ changed over time. Expression of CCL2 was highest on d 4 postpartum [RQ: 3.9 (2.2-6.7)] compared with the lowest expression on d 28 prepartum [RQ: 1.8 (1.1-3.2), $P=0.03]$, and the highest expression of $T N F \alpha$ was measured on d 21 postpartum [RQ: 1.9 (1.4-2.7)] compared with the lowest expression on d 28 prepartum [RQ: $1.0(0.7-1.4), P=0.03]$. We did not detect group differences or interactions between group and time for expression of these 2 inflammatory genes $(P>0.22)$. 

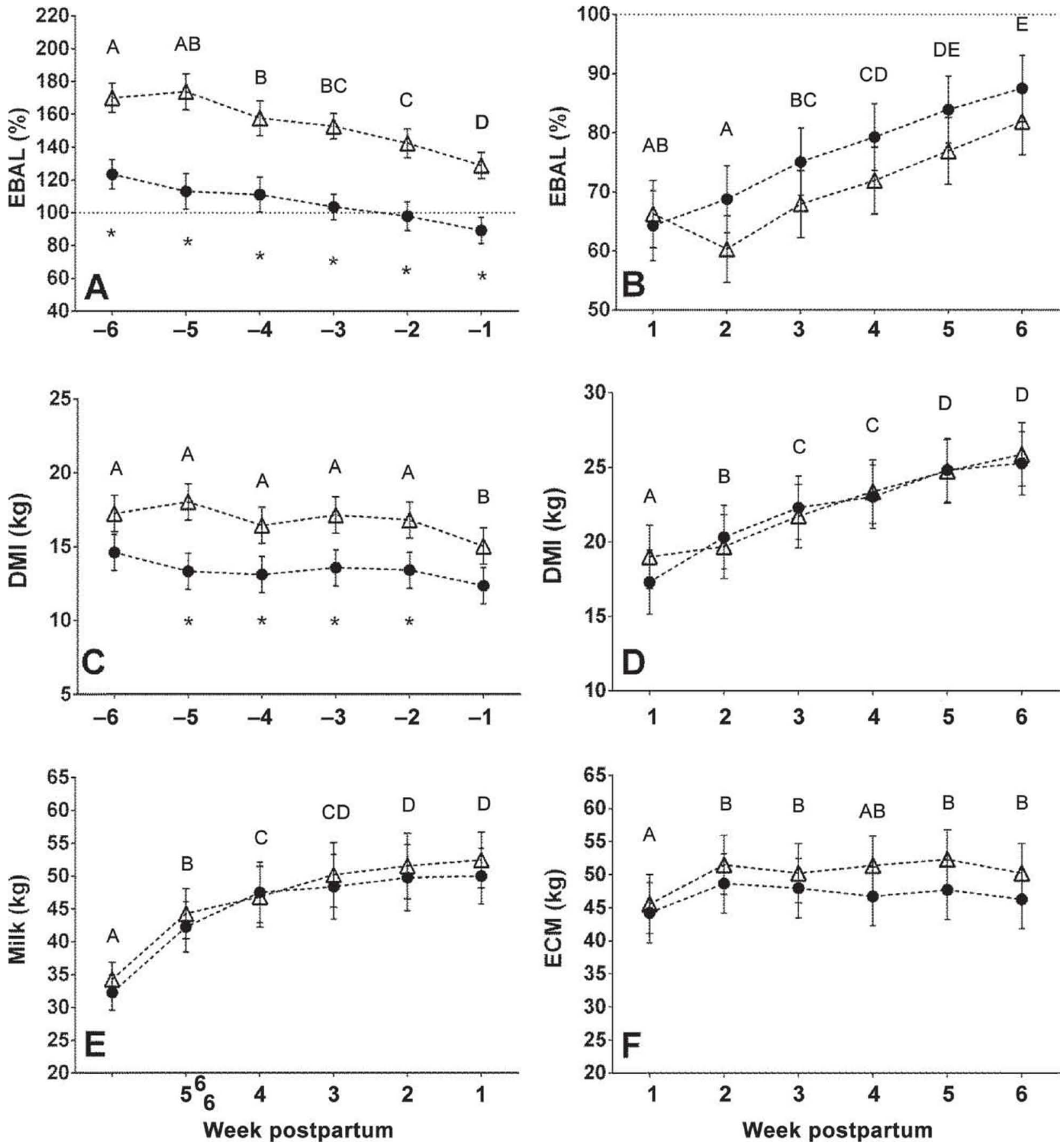

Figure 1. Energy balance (EBAL in \% of predicted requirements), DMI, and milk production of selected study animals. Least squares means of prepartum energy balance (A) and DMI (C), and postpartum energy balance (B) and DMI (D). Least squares of average weekly milk production (E) and ECM (F) in kg for wk 1 to 6 postpartum. Data presented as LSM and 95\% CI. Time points marked with different letters (A-E) and groups at each time point marked with * differ at a level of $P<0.05$ in repeated measures ANOVA and Tukey's post hoc test. Energy balance prepartum: group $P<0.0001$, time $P<0.0001$, group $\times$ time $P=0.12$; EBAL postpartum: group $P=0.05$, time $P<0.0001$, group $\times$ time $P=0.25$; DMI prepartum: group $P<0.0001$, time $P<0.0001$, group $\times$ time $P=0.19$; DMI postpartum: group $P=0.85$, time $P<0.0001$, group $\times$ time $P=0.34$; milk kg: group $P=0.46$, time $P<0.0001$, group $\times$ time $P=0.38$; ECM kg: group $P=0.22$, time $P=0.004$, group $\times$ time $P=0.88$. Controlled $(\mathrm{n}=12)$ : cows fed a controlled-energy diet during the prepartum period, supplying approximately $100 \%$ of predicted energy requirements and with the low BHB concentrations postpartum. High $(\mathrm{n}=12)$ : cows fed a high-energy diet during the prepartum period, supplying approximately $150 \%$ of predicted energy requirements and with high BHB concentrations postpartum. 
Table 1. Blood concentrations of BHB, nonesterified fatty acids (NEFA), glucose, and insulin in study animals on the day of biopsy (results presented as mean and $95 \% \mathrm{CI}$ )

\begin{tabular}{|c|c|c|c|}
\hline \multirow[b]{2}{*}{ Item } & \multicolumn{2}{|c|}{ Group $^{1}$} & \multirow[b]{2}{*}{$P$-value } \\
\hline & Controlled $(\mathrm{n}=12)$ & $\operatorname{High}(\mathrm{n}=12)$ & \\
\hline \multicolumn{4}{|c|}{ NEFA (mmol/L) } \\
\hline-28 & $0.37(0.30-0.44)$ & $0.35(0.29-0.42)$ & 0.74 \\
\hline-10 & $0.40(0.29-0.51)$ & $0.44(0.33-0.55)$ & 0.63 \\
\hline+4 & $1.35(1.18-1.52)$ & $1.82(1.64-1.99)$ & 0.001 \\
\hline+21 & $1.02(0.82-1.22)$ & $1.44(1.24-1.63)$ & 0.005 \\
\hline \multicolumn{4}{|c|}{$\mathrm{BHB}(\mathrm{mmol} / \mathrm{L})$} \\
\hline-28 & $0.23(0.17-0.28)$ & $0.24(0.18-0.30)$ & 0.73 \\
\hline-10 & $0.32(0.25-0.40)$ & $0.25(0.18-0.33)$ & 0.22 \\
\hline+4 & $0.69(0.45-0.93)$ & $1.20(0.96-1.44)$ & 0.005 \\
\hline+21 & $0.63(0.18-1.08)$ & $1.49(1.04-1.94)$ & 0.01 \\
\hline \multicolumn{4}{|c|}{ Glucose (mg/dL) } \\
\hline-28 & $71.9(68.4-75.4)$ & $76.4(73.0-79.9)$ & 0.07 \\
\hline-10 & $69.8(66.2-73.4)$ & $74.9(71.4-78.4)$ & 0.05 \\
\hline+4 & $61.1(58.1-64.1)$ & $53.2(50.2-56.2)$ & 0.001 \\
\hline+21 & $65.1(60.4-69.8)$ & $56.9(52.3-61.6)$ & 0.01 \\
\hline \multicolumn{4}{|c|}{ Insulin $(\mu \mathrm{U} / \mathrm{mL})$} \\
\hline-28 & $17.7(13.9-21.4)$ & $18.3(14.8-21.9)$ & 0.80 \\
\hline-10 & $11.7(8.7-14.8)$ & $11.7(8.6-14.7)$ & 0.99 \\
\hline+4 & $2.5(1.4-3.5)$ & $0.9(0.2-1.9)$ & 0.03 \\
\hline+21 & $5.9(4.2-7.6)$ & $3.2(1.6-4.8)$ & 0.02 \\
\hline
\end{tabular}

${ }^{1}$ Controlled $(\mathrm{n}=12)$ : cows fed a controlled-energy diet during the prepartum period, supplying approximately $100 \%$ of predicted energy requirements and with the low BHB concentrations postpartum. High $(\mathrm{n}=12)$ : cows fed a high-energy diet during the prepartum period, supplying approximately $150 \%$ of predicted energy requirements and with high $\mathrm{BHB}$ concentrations postpartum.

\section{$\triangle$ High Controlled}
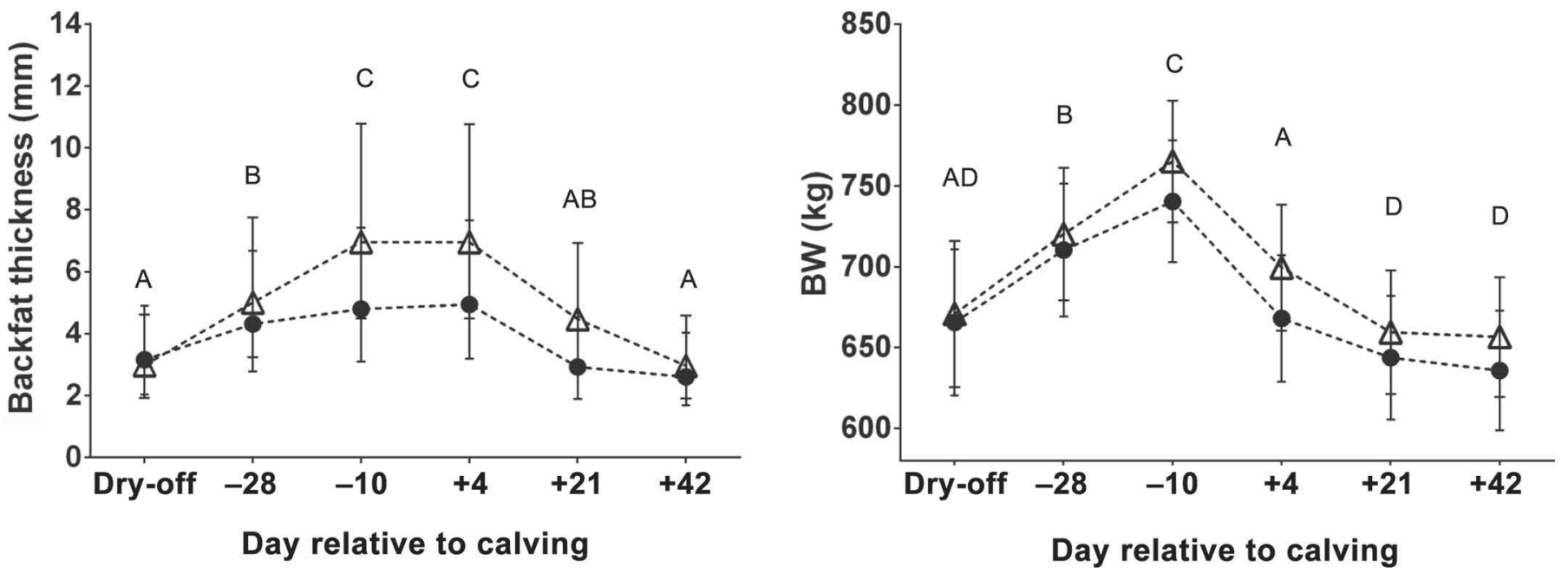

Figure 2. Least squares means of backfat thickness (BFT) in the thurl area in millimeters (left) and BW in kilograms (right) of study animals at 6 different time points throughout the study. Time points marked with different letters $(\mathrm{A}-\mathrm{D})$ differ at a level of $P<0.05$ after Tukey's honestly significant difference test. Error bars represent 95\% CI. $P$-values derived from repeated measures ANOVA: BFT: group $P=$ 0.42 , time $P<0.0001$, group $\times$ time $P=0.04$; weight: group $P=0.50$, time $P<0.0001$, group $\times$ time $P=0.11$. Controlled (n $=12$ ): cows fed a controlled-energy diet during the prepartum period, supplying approximately $100 \%$ of predicted energy requirements and with the low BHB concentrations postpartum. High $(\mathrm{n}=12)$ : cows fed a high-energy diet during the prepartum period, supplying approximately $150 \%$ of predicted energy requirements and with high BHB concentrations postpartum. 


\section{Adipose Tissue Immunoblotting}

The total amount of AKT and HSL in relation to $\beta$-actin quantified by densitometry changed over time: the ratio of AKT: $\beta$-actin declined from $1.3(1.2-1.5)$ on $28 \mathrm{~d}$ prepartum to $1.2(1.0-1.4)$ and was $1.0(0.9-1.2)$ on $\mathrm{d} 4$ and $1.1(1.0-1.2)$ on $\mathrm{d} 21$ postpartum $(P=$
0.02). The ratio of HSL: $\beta$-actin also declined from 1.0 $(0.9-1.2)$ on d 28 prepartum to $0.7(0.6-0.9)$ on d 10 prepartum, $0.7(0.6-0.8)$ on $\mathrm{d} 4$, and $0.8(0.7-0.9)$ on $\mathrm{d}$ 21 postpartum $(P=0.003)$. In contrast, total amounts of ERK showed no change over time $(P=0.30)$. Group differences and interactions between time and group were not observed $(P>0.36)$.
FASN
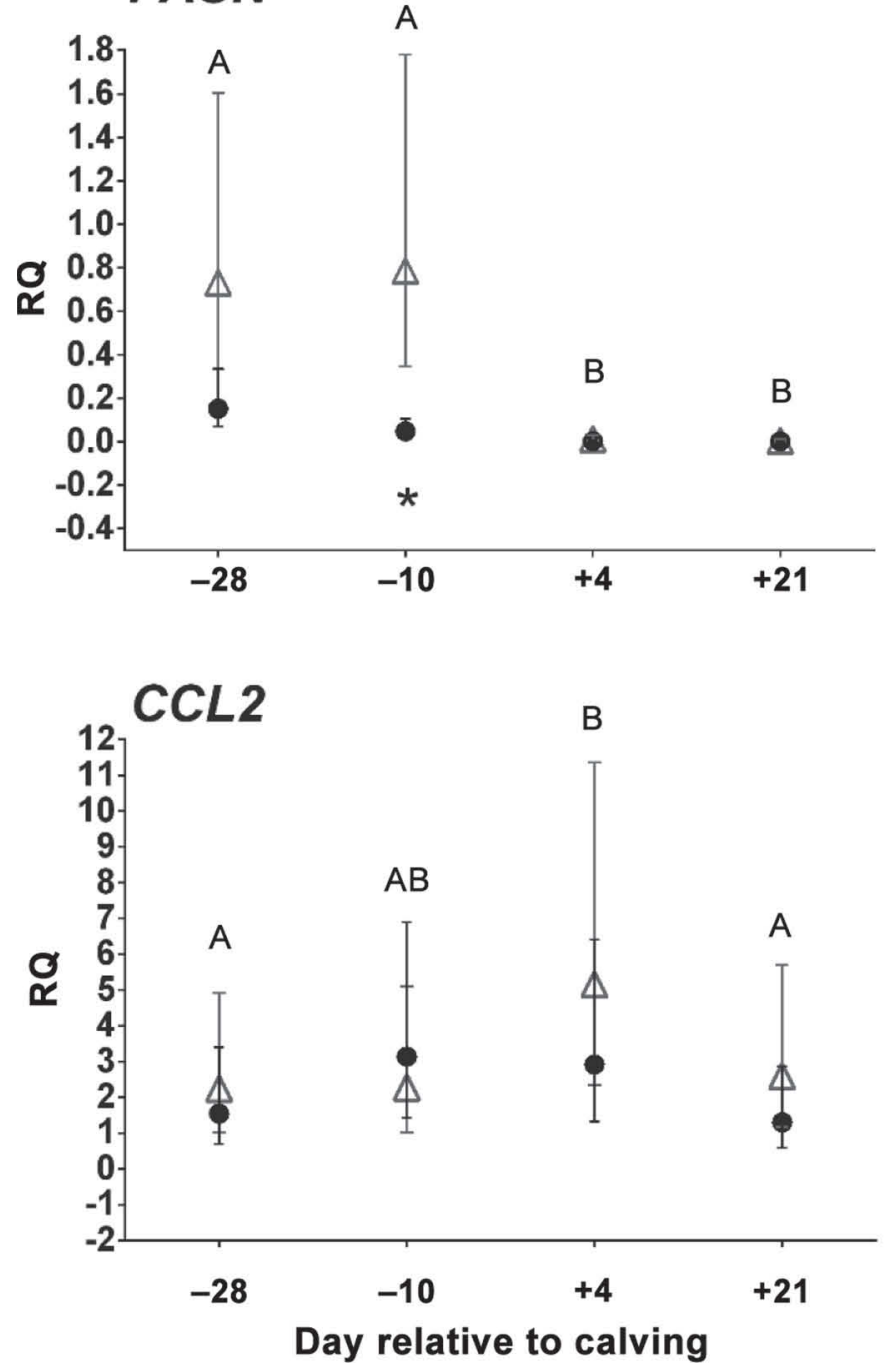

\section{$\triangle$ High $\bullet$ Controlled} ADIPOQ

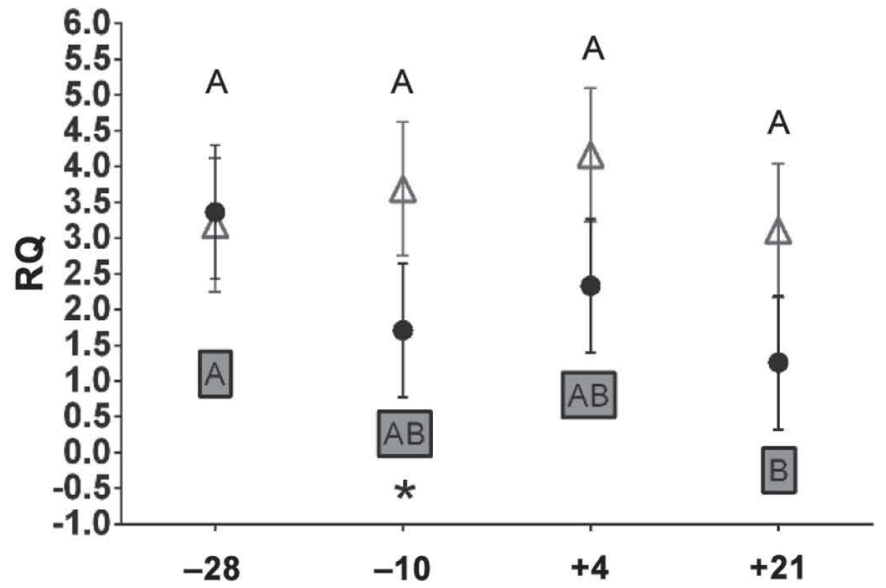

\section{$T N F \alpha$}

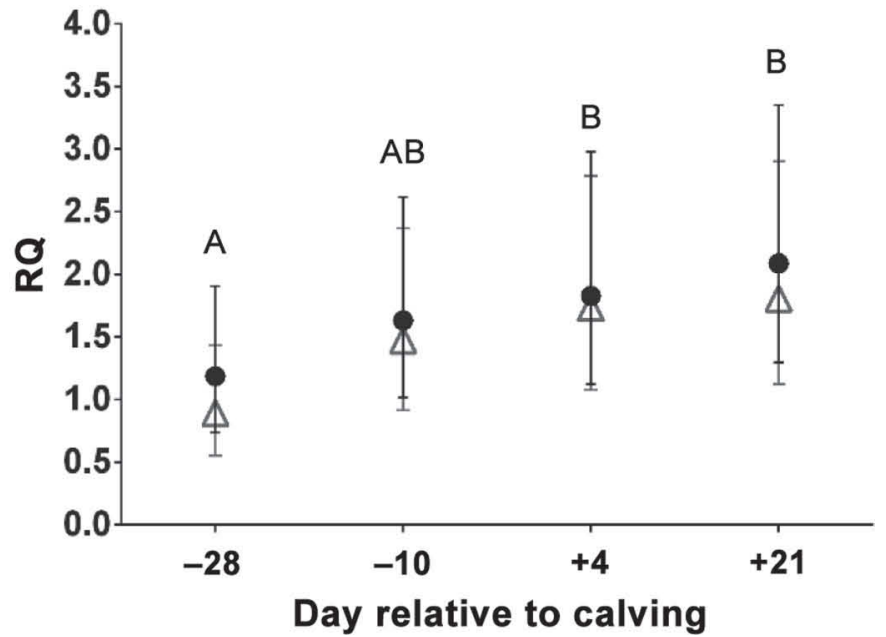

Figure 3. Gene expression (relative quantity, RQ) measured by real-time quantitative reverse-transcription PCR in subcutaneous adipose tissue biopsies at 4 time points in the peripartum period. Results presented as geometric least squares means and $95 \%$ CI. Differences over time are marked with different letters (A,B) differ at a level of $P<0.05$ in repeated measures ANOVA and Tukey's test; differences between groups are depicted as $* P<0.05$. The interaction between group and time is depicted in letters (A,B) for group $\mathrm{H}$ and shaded letters (A,B) for group C. $F A S N=$ fatty acid synthase, group $P<0.001$, time $P<0.0001$, group $\times$ time $P=0.08 ; A D I P Q=$ adiponectin, group $P=0.004$, time $P$ $=0.04$, group $\times$ time $P=0.04 ; C C L 2=$ chemokine ligand $2 /$ monocyte chemotactic protein- 1 , group $P=0.50$, time $P=0.01$, group $\times$ time $P$ $=0.22, T N F \alpha=$ tumor necrosis factor $\alpha$, group $P=0.43$, time $P=0.01$, group $\times$ time $P=0.89$. Controlled $(\mathrm{n}=12)$ : cows fed a controlledenergy diet during the prepartum period, supplying approximately $100 \%$ of predicted energy requirements and with the low BHB concentrations postpartum. High $(\mathrm{n}=12)$ : cows fed a high-energy diet during the prepartum period, supplying approximately $150 \%$ of predicted energy requirements and with high BHB concentrations postpartum. 


\section{$\triangle$ High $\bullet$ Controlled}

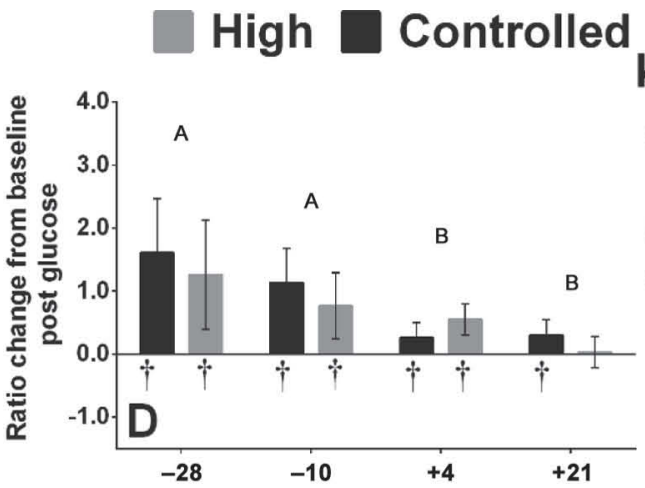

\section{kD \\ 60 \\ (AKT (Ser473)}

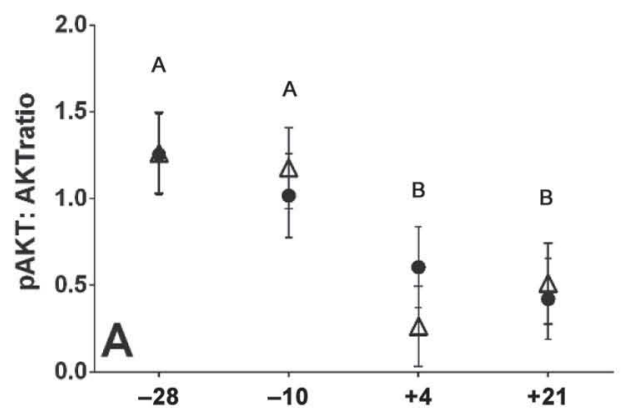

Glu $\frac{-+ \pm}{-28} \frac{-+\frac{+}{-10}}{+4} \frac{++}{+21} \mathrm{ctr}$
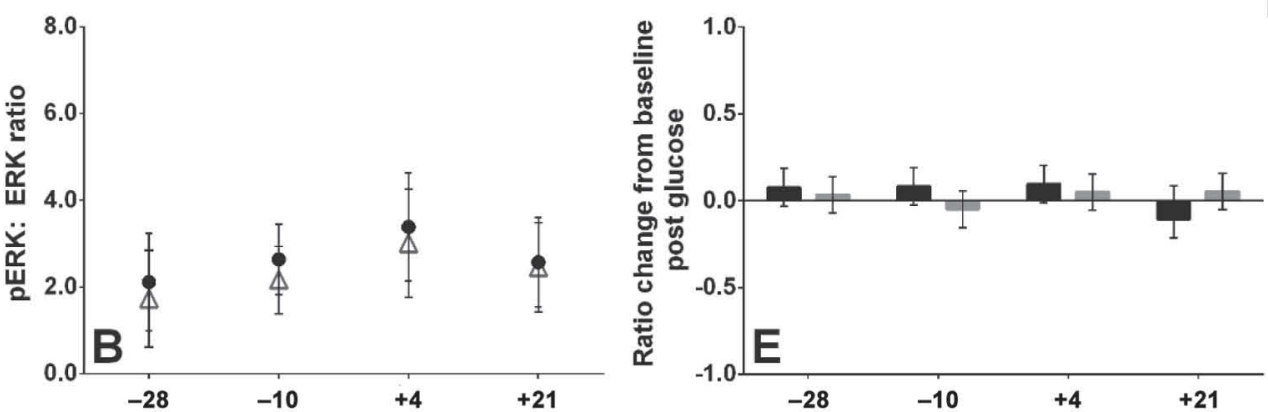

kD
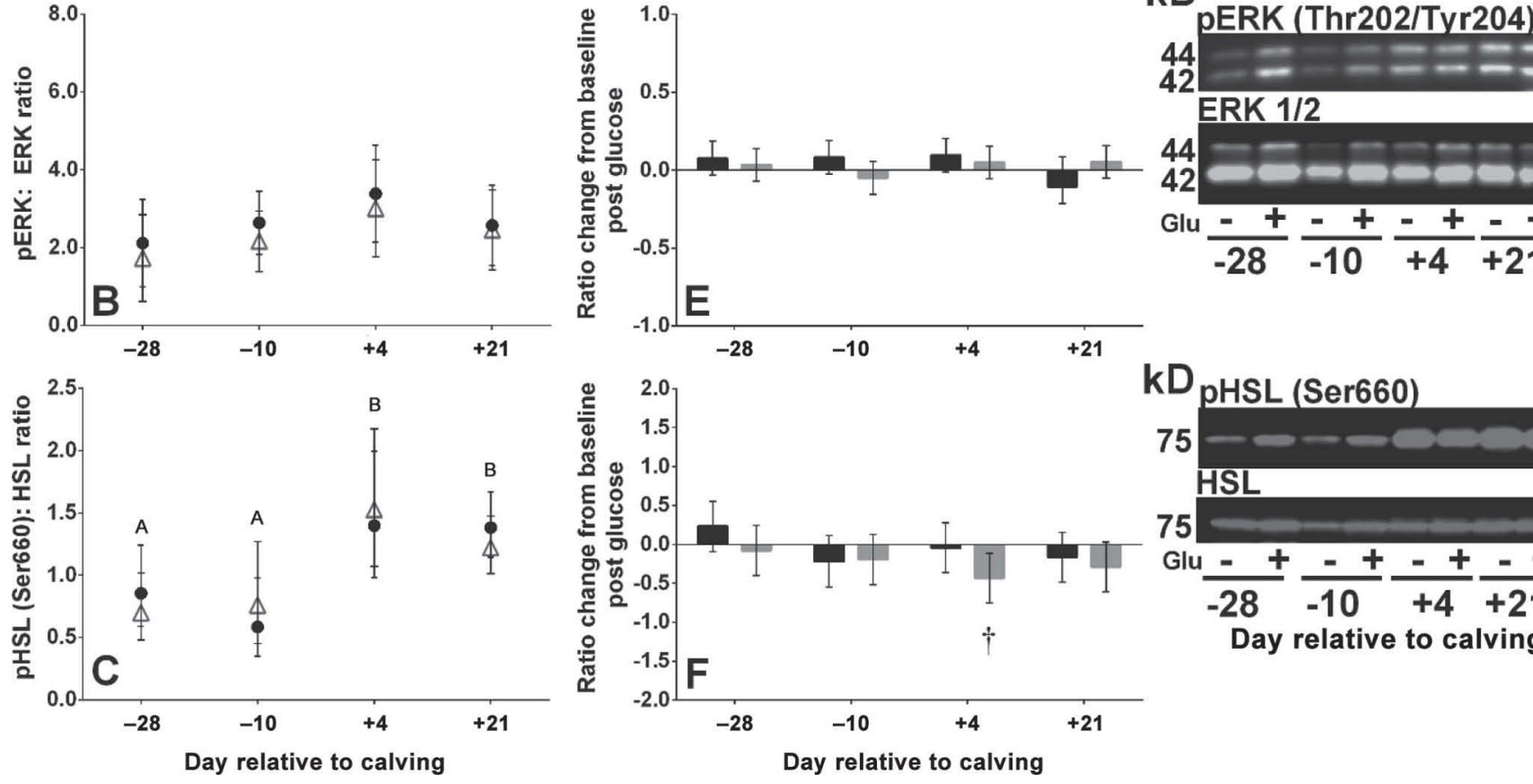

$\mathrm{kD}_{\mathrm{pHSL}}$ (Ser660)

75 HSL

75

Glu $-+++\frac{-+++}{-2 t r}$

Figure 4. Results of immunoblot densitometry and resulting ratio for phosphorylated proteins of interest before (left panel) and after glucose infusion (middle panel) and representative blots of adipose tissue in the peripartum period (right panel). Least squares geometric means of the ratio of phosphorylated (p) protein kinase B (AKT; Ser473):AKT (A), phosphorylated extracellular signal-regulated kinase (ERK; Thr202/Tyr204):ERK (B), and pHSL(Ser660):HSL (C) proteins before glucose infusion and difference in the ratio of pAKT(Ser473):AKT (D), pERK(Thr202/Tyr204):ERK (E), and phosphorylated hormone-sensitive lipase (HSL; Ser660):HSL (F), 60 min after glucose infusion (Glu). Results presented as geometric mean and 95\% CI. Time points marked with different letters (A,B) differ at a level of $P<0.05$ in repeated measures ANOVA and Tukey's test; $\dagger$ marks difference from baseline is different from $0(P<0.05)$. Controlled $(\mathrm{n}=12)$ : cows fed a controlledenergy diet during the prepartum period, supplying approximately $100 \%$ of predicted energy requirements and with the low BHB concentrations postpartum. High $(\mathrm{n}=12)$ : cows fed a high-energy diet during the prepartum period, supplying approximately $150 \%$ of predicted energy requirements and with high $\mathrm{BHB}$ concentrations postpartum. The $P$-values of repeated measures ANOVA: pAKT:AKT: group $P=0.85$, time $P<0.001$, group $\times$ time $P=0.02$; pERK:ERK: group $P=0.48$, time $P=0.15$, group $\times$ time $P=0.97$; pHSL:HSL: group $P=0.97$, time $P=$ 0.001 , group $\times$ time $P=0.72$; change in pAKT:AKT: group $P=0.48$, time $P=0.001$, group $\times$ time $P=0.14$; change in pERK:ERK: group $P$ $=0.33$, time $P=0.55$, group $\times$ time $P=0.62$; change in pHSL660:HSL: group $P=0.20$, time $P=0.09$, group $\times$ time $P=0.46$.

The ratios of pAKT:AKT, pERK:ERK, and pHSL (Ser660):HSL are presented in Figure 4. The ratio of pAKT:AKT changed over time with the lowest values on d 4 and 21 postpartum compared with both d 28 and 10 prepartum, and an interaction between group and time $(P=0.02)$ was present. The correlation coefficient between resting concentrations of insulin and phosphorylation of AKT was $0.64(P<0.0001)$. The increase in the ratio of phosphorylated AKT $60 \mathrm{~min}$ after glucose infusion also changed over time with the greatest increase on d 28 prepartum [1.43 (0.83-2.03)], and the smallest increase on $\mathrm{d} 21$ postpartum $[0.16$ $(-0.01-0.32)]$, but no differences were observed between the groups $(P=0.82)$. At all time points, the 
average difference from baseline was greater than 0 at a level of $P<0.05$ except on $d 21$ postpartum in group H. However, 4 cows on d 4 postpartum (2 in group C, 2 in group $\mathrm{H}$ ) and 10 cows on d 21 postpartum (4 in group $\mathrm{C}, 6$ in group $\mathrm{H}$ ) had no detectable increase in phosphorylation ratio of AKT 60 min postglucose $(P>$ 0.68). No differences in BW or BCS loss within the first 3 and $6 \mathrm{wk}$, respectively, were observed for these cows in comparison with cows that did have an increase in AKT phosphorylation $(P>0.60)$.

The ratio of pERK:ERK was not different over time or between treatment groups $(P>0.13$; Figure 4$)$. The ratio of pHSL (Ser660):HSL changed over time $(P=$ 0.001 ) with the largest ratio on $\mathrm{d} 4$ postpartum $[1.46$ $(1.14-1.87)]$ in both groups compared with d 10 prepartum [0.66 (0.47-0.96), $P=0.002]$, but no difference was observed between groups $(P=0.81$; Figure 4$)$. A difference from baseline in the ratio of pHSL (Ser660) after glucose infusion was only detected on d 4 postpartum in group H. Similarly, the ratio of pHSL (Ser563) was also not different between groups $(P=0.56)$, but the ratio increased from $1.03(0.72-1.45)$ on d 28 prepartum and $0.63(0.31-1.21)$ on d 10 prepartum to 4.07 (2.50-6.68) on d 4 postpartum and 2.59 (1.03-6.51) on d 21 postpartum. The ratios on d 28 and 10 prepartum were lower than on $\mathrm{d} 4$ postpartum $(P<0.002)$, and the ratio on $\mathrm{d} 10$ prepartum was lower than on $\mathrm{d} 21$ postpartum $(P=0.02)$.

We found no group differences or interactions between group and time in densitometry results for the ratio of INSR: $\beta$-actin and PPAR $\gamma: \beta$-actin $(P>0.51)$, but a difference over time was noted with a decrease in INSR on d 10 prepartum [0.80 (0.62-1.04)] and d 21 postpartum [0.80 (0.62-1.04)] compared with d 28 prepartum [1.37 (1.06-1.77) $P<0.004$; Figure 5]. The ratio of PPAR $\gamma$ was lower on d 4 [1.49 (1.06-2.08)] compared with d 21 [2.59 (1.85-3.63), $P=0.01]$ postpartum.

\section{DISCUSSION}

\section{Adipogenesis and Lipolysis}

Expression of the classic lipogenic gene FASN in subcutaneous adipose tissue of cows overfed energy during the dry period was increased compared with cows fed a controlled-energy diet. Ji et al. (2012) found a similarly greater expression of FASN in subcutaneous adipose tissue of moderately overfed cows at d 10 prepartum. Upregulation of expression of this gene was also found in subcutaneous adipose tissue of overfed nonpregnant, nonlactating cows (Hosseini et al., 2015). Based on those differences and the greater increase in weight prepartum, it is likely that adipose tissue mass was greater in cows in group $\mathrm{H}$ compared with group $\mathrm{C}$ despite an absence in differences in BCS. In a recent study, Drackley et al. (2014) showed that visceral adipose tissue mass increased due to overfeeding in nonlactating dairy cows compared with those fed a low-energy diet with approximately double the mass in omental, mesenteric, and perirenal fat, but that BCS was not different at the end of the feeding period. It is therefore possible that cows overfed energy in this study accrued additional adipose tissue in visceral depots that did not translate into a greater BCS.

Phosphorylation of HSL at serine residues 563 and 660 is induced by catecholamines and plays a role in the activation of this enzyme, which facilitates triglyceride hydrolysis together with adipocyte triacylglycerol lipase (Yeaman et al., 1994; Frühbeck et al., 2014). Phosphorylation of HSL is increased in the postpartum period in dairy cattle (Locher et al., 2011). We did not observe a difference in phosphorylation levels of HSL (both Ser563 and Ser660) between the 2 groups at any time point despite higher concentrations of serum NEFA during the postpartum period in cows in group H. However, both serine residues had significantly higher phosphorylation ratios postpartum, indicating increased HSL activity on d 4 and 21 postpartum irrespective of prepartum dietary treatment. This corresponds with the increase in $\beta$-adrenergic receptor activity in adipose tissue of postpartum dairy cows (Jaster and Wegner, 1981; Bell, 1995). Feeding diets differing in concentrate ratio postpartum did not lead to a detectable effect on HSL phosphorylation ratios of subcutaneous adipose tissue in the study by Locher et al. (2011), but phosphorylation ratios were increased on d 1 and 21 in subcutaneous and retroperitoneal adipose tissue in both groups. Taken together, the study by Locher et al. (2011) and our study found no association between HSL phosphorylation in the peripartum period and dietary energy level either during the pre- or postpartum period.

We also observed a decrease in the total amount of HSL protein after d 28 prepartum in both groups. This finding is in accordance with the results of Locher et al. (2011) who also observed a reduced quantity of this protein in subcutaneous adipose tissue and which they attributed to a possible feedback mechanism due to increased blood NEFA concentrations. We observed the decrease in HSL starting on d 10 prepartum, before a large increase in NEFA concentration took place. This makes a direct feedback regulation in response to increased NEFA concentrations less likely. Locher et al. (2011) hypothesized that BHB might have an inhibitory effect on phosphorylation of HSL at Ser563. However, in the present study, we observed no difference in the 


\section{High Controlled}

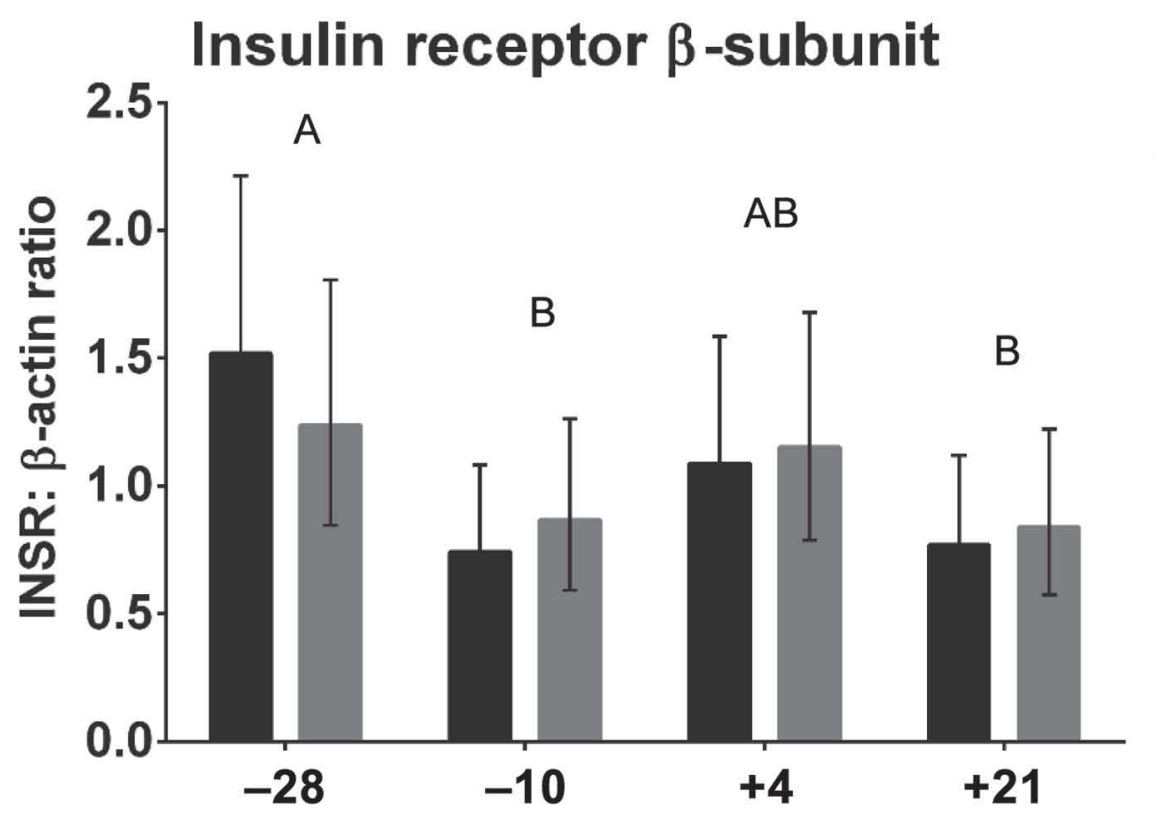

\section{kD INSR $\beta$-subunit}

95
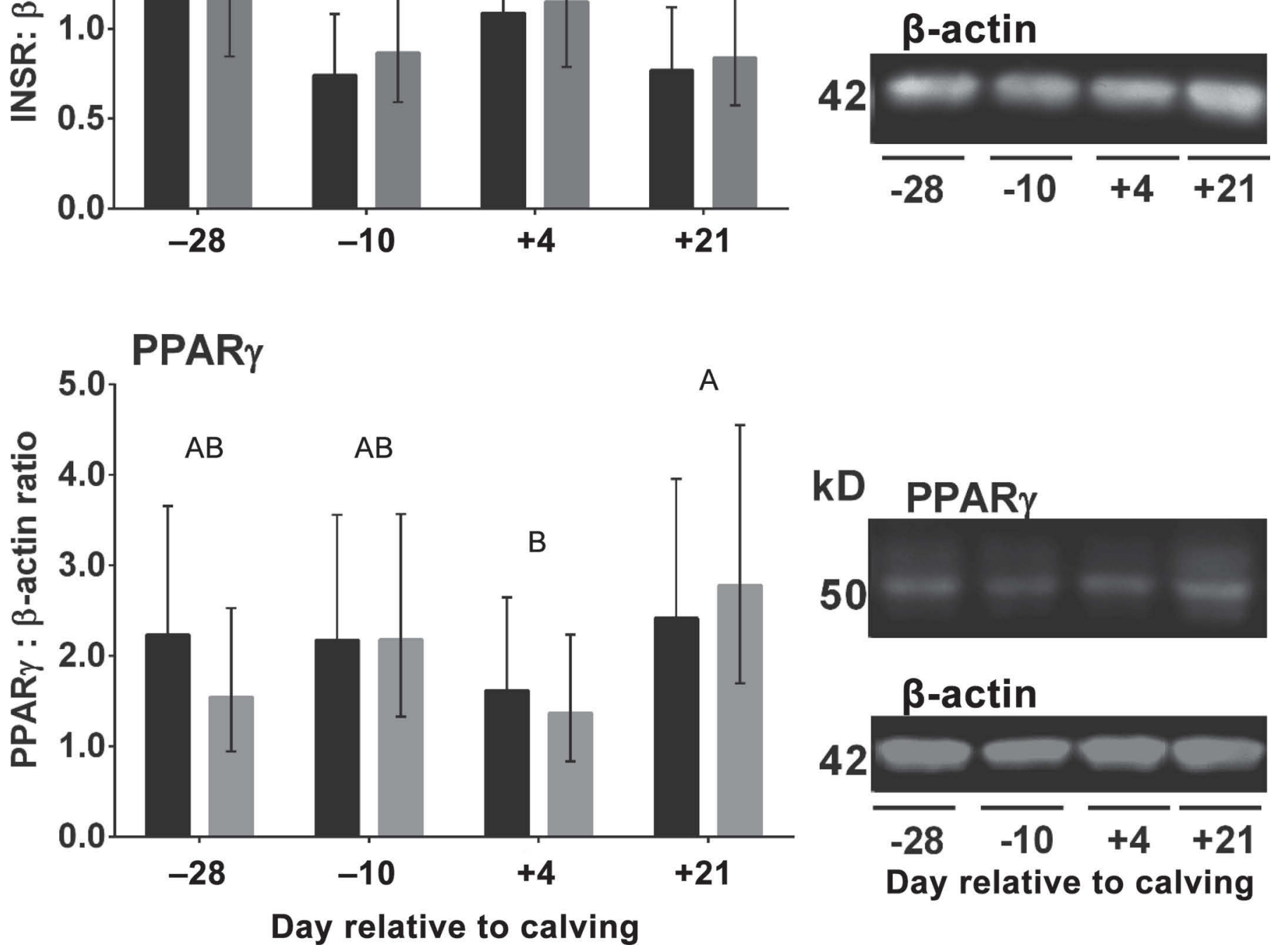

kD PPAR $\gamma$

50

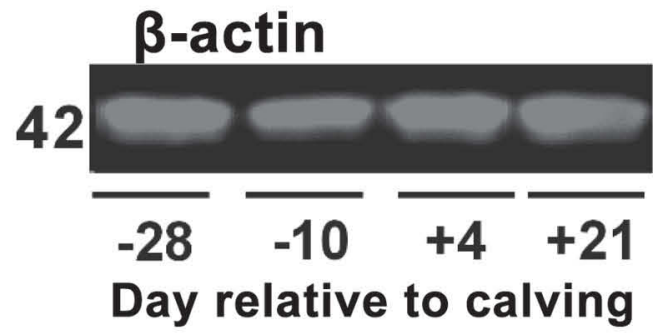

Figure 5. Least squares means of immunoblotting densitometry results for insulin receptor-(INSR)- $\beta$ (top) and peroxisome proliferatoractivated receptor (PPAR) $-\gamma$ (bottom) as well as representative blots for each protein; $\beta$-actin served as the loading control. Results presented as geometric mean and $95 \%$ CI. Time points marked with different letters (A,B) differ at a level of $P<0.05$ in repeated measures ANOVA and Tukey's test. $P$-values of repeated measures ANOVA: INSR: group $P=0.91$, time $P=0.001$, group $\times$ time $P=0.65$; PPAR $\gamma$ : group $P=0.75$, time $P=0.02$, group $\times$ time $P=0.47$. 
ratio of pHSL (Ser563) to total HSL between cows with high and low BHB concentrations postpartum.

\section{Insulin Signaling}

We found an interaction between group and time at the level of baseline insulin signaling through AKT due to the numerically lower phosphorylation ratio in group $\mathrm{H}$ on $\mathrm{d} 4$ postpartum. Based on the correlation between baseline concentrations of insulin and AKT phosphorylation, we attributed this to the lower resting blood concentrations of insulin on this day in group $\mathrm{H}$. Zachut et al. (2013) did not find an increase in AKT phosphorylation following a glucose challenge in subcutaneous adipose tissue in 4 out of 8 Holstein cows pre- as well as postpartum and identified these cows as being prone to high weight loss postpartum. All animals were fed the same diet prepartum (1.46 Mcal of $\mathrm{NE}_{\mathrm{L}} / \mathrm{kg}$ of $\left.\mathrm{DM}\right)$. The authors concluded that animals with increased body condition loss and increased milk production were suffering from adipose-tissue-specific insulin resistance. In the present study, the average AKT phosphorylation 60 min after glucose challenge was different from baseline for all groups and sampling time points except $d$ 21 postpartum in group $\mathrm{H}$. No difference in weight loss was found between animals that did and did not have an increase in the ratio of AKT phosphorylation after glucose challenge in our study. The difference between the study by Zachut et al. (2013) and our own is that all 24 cows in our present study showed an increase in AKT phosphorylation prepartum, whereas the 4 cows in the study by Zachut et al. (2013) already exhibited an absence of increase in phosphorylation prepartum. We therefore assume that differences existed between cows used in these 2 studies, either due to genetics, body condition, or due to differences in nutrition and management. In addition, we took samples 60 min after glucose infusion, whereas in the study by Zachut et al. (2013) samples were taken between 25 and 30 min after glucose infusion. Although maximal insulin concentrations are reached between approximately 7 to $13 \mathrm{~min}$ in lactating and dry cows, respectively (Mann et al., 2016), the increased timespan that adipose tissue was exposed to high circulating concentrations of insulin in vivo in our study could have resulted in the observed differences.

As reported previously (Mann et al., 2016), neither glucose clearance, insulin response to the glucose challenge, nor reduction in NEFA concentration during the IVGTT were different at any time between the groups. In accordance with this data, Ji et al. (2012) studied the effect of moderate overfeeding during the dry period on peripartal gene expression of adipose tissue insulin signaling, adipogenesis, and lipolysis, and concluded that rather than compromising the insulin signaling pathway in subcutaneous adipose tissue, signaling was increased in overfed cows, particularly in late pregnancy. In a recent study, De Koster et al. (2016) tested the inhibitory effect of insulin on catecholamine-stimulated subcutaneous and omental lipolysis. The authors found that overconditioning of dry cows had no effect on the inhibitory effect of insulin on lipolysis at physiological concentrations (De Koster et al., 2016). Together, these and our own study suggest that overfed and overconditioned dry cows do not suffer from decreased insulin sensitivity in adipose tissue.

No difference was found in ERK phosphorylation ratios over the transition period, following a glucose challenge, or between groups. This could be interpreted either that phosphorylation ratios of ERK do not change detectably after binding of insulin to its receptor, such as after an insulin stimulus in bovine adipose tissue, or that activation of ERK plays a secondary role in insulin-induced signaling compared with AKT.

Changes in insulin receptor abundance have previously been assessed on the level of gene expression in cows fed different energy levels in the dry period (Ji et al., 2012) and in accordance with our study, no difference was found between groups overfed energy or fed a controlled-energy diet in the dry period. We observed a decrease in the protein amount of the $\beta$-subunit of the insulin receptor from d 28 prepartum compared with d 10 prepartum and d 21 postpartum, which we interpret as part of the adaptation to lactation and the reduced concentrations of circulating insulin. In contrast to our findings, Ji et al. (2012) and Sadri et al. (2010) did not observe changes of insulin receptor mRNA abundance in the peripartum period. Differences between these and our own study could be due to the choice of sampling time points and a discrepancy between transcription and translation as well as posttranslational modifications.

\section{PPARY, Adiponectin, and Markers of Inflammation}

A central regulator of adipocyte biology and energy homeostasis is the transcription factor PPAR $\gamma$, which induces adipogenic gene expression, remodeling of adipose tissue, and adipokine secretion (Astapova and Leff, 2012). In accordance with the results of Selim et al. (2014) who measured expression of PPARG in subcutaneous adipose tissue, no difference between groups fed a high- or controlled-energy diet in the dry period was observed for PPAR $\gamma$. In contrast, Ji et al. (2012) found a greater expression of $P P A R G$ in subcutaneous adipose tissue of moderately overfed cows at d 10 
prepartum and $\mathrm{d} 7$ postpartum. The amount of PPAR $\gamma$ was lower early postpartum compared with $21 \mathrm{~d}$ postpartum in both groups in the current study. A decrease in PPARG expression postpartum in subcutaneous adipose tissue and liver was also described by Saremi et al. (2014) who measured the expression of this gene in 2 groups of cows (fed conjugated linoleic acid or a control diet after calving) and found a decrease in expression of PPARG in both tissues shortly after parturition. Because activation of PPAR $\gamma$ increases glucose uptake into adipose tissue (Ahmadian et al., 2013), the decrease in expression might reflect the reduced availability of glucose during this time.

We observed an interaction between group and time for expression of $A D I P O Q$ with a decrease of expression in the controlled-energy group after d 28 prepartum compared with the high-energy group. A tendency for greater gene expression of $A D I P O Q$ in cows overfed energy during the dry period has previously been observed by Ji et al. (2012), and the difference was greatest on $\mathrm{d}-10$ and 7 relative to parturition, which corresponds to the time points when we observed differences in the present study. The authors of the study by Ji et al. (2012) hypothesized that this difference might have been driven by the greater expression of $P P A R G$ in their study and allowed the adipose tissue to retain insulin sensitivity despite overfeeding of energy. An upregulation of $A D I P O Q$ in the absence of concurrent increase in PPARG in subcutaneous adipose tissue of nonpregnant, nonlactating cows was reported recently by Hosseini et al. (2015), but the authors observed a numerical increase in protein expression of PPAR $\gamma$ in the overfed group. In contrast, our study did identify a difference between $A D I P O Q$, but not PPAR $\gamma$, between the treatment groups as described above. This difference could have been due to the fact that we semiquantitatively determined PPAR $\gamma$ protein expression, whereas Ji et al. (2012) measured differences on the level of gene expression. However, we did not assess the activation state of this nuclear receptor directly and small, but potentially biologically significant differences between groups could have existed that we were not able to detect by the semiquantitative method of immunoblotting used in our study.

In a study investigating the change of mRNA expression in subcutaneous adipose tissue in high-yielding dairy cows, Lemor et al. (2009) did not observe changes of $A D I P O Q$ between the week prepartum to 3 wk postpartum. In contrast, $A D I P O Q$ expression in subcutaneous adipose tissue of cows fed a controlled-energy diet during the dry period was reduced from $28 \mathrm{~d}$ prepartum to $21 \mathrm{~d}$ postpartum and was significantly lower than that of the high-energy group in our study. Differences between our study and the findings of Lemor et al. (2009) could be due to the fact that we had one additional time point ( $28 \mathrm{~d}$ prepartum) before downregulation of mRNA expression occurred. Furthermore differences could have been due to prepartum dietary energy level, which was not reported in the study by Lemor et al. (2009) and could have resembled the high-energy group in our study rather than the controlled-energy group where we observed a reduction in expression. In accordance with our results, Giesy et al. (2012) found no reduction of mRNA expression in subcutaneous adipose tissue from late pregnancy to early lactation in cows fed a high-energy TMR (1.63 Mcal of $\mathrm{NE}_{\mathrm{L}} /$ $\mathrm{kg}$ of DM) ad libitum during the dry period. However, circulating blood concentrations were decreased in the immediate peripartum period, which is in accordance with the results reported by others (Mielenz et al., 2013; Kabara et al., 2014; Singh, 2014). Hosseini et al. (2015) observed that gene expression of $A D I P O Q$ in subcutaneous adipose tissue did not correlate with blood concentrations. Taken together, these studies suggest that cows fed a high-energy diet prepartum might not experience the same degree of downregulation of $A D I P O Q$ expression as cows fed a controlled-energy diet, but that circulating concentrations in blood may still decrease in the immediate postpartum period.

In human and rodent models, excess energy intake and obesity are associated with a proinflammatory state of the adipose tissue, which is thought to play a role in the development of metabolic dysfunction and insulin resistance (Bai and Sun, 2015). In humans, hypertrophic adipocytes secrete low levels of $\mathrm{TNF} \alpha$ and the stromal vascular fraction of adipose tissue increases expression of $C C L 2 / M C P 1$, leading to infiltration of macrophages and a low-grade inflammatory status of the tissue (Capurso and Capurso, 2012). The results of our study showed that expression of adipose tissue $C C L 2 / M C P 1$ was not different between groups, suggesting that a high prepartal plane of energy, increased rate of mobilization of NEFA, and high concentrations of BHB did not affect the production of this chemokine compared with the controlled-energy group. However, the presence of inflammatory cells in adipose tissue biopsies in the present study was not measured directly. Akter et al. (2012) assessed the proportion of infiltrating macrophages of various adipose tissue locations (subcutaneous and visceral) in early-lactation Holstein cows as well as nonpregnant, nonlactating Holstein heifers by immunohistochemistry and concluded that the extent of obesity in early lactation did not contribute to increased infiltration of phagocytic cells and that the overall proportion of samples with phagocytic immune cell infiltration was low in cows in early lactation. 
In accordance with our study, Ji et al. (2014a) did not observe a difference in the expression of $T N F \alpha$ between nonpregnant, nonlactating Holstein cows overfed energy or fed a controlled-energy diet and concluded that overfeeding did not induce an overt inflammatory response in adipose tissue. Selim et al. (2014) measured expression of $T N F \alpha$ in subcutaneous adipose tissue of cows either overfed energy or fed a controlled-energy diet for the last 6 wh prepartum and found no effect of energy level throughout the transition period. Saremi et al. (2014) found only a weak or no correlation between expression of $T N F \alpha$ in adipose tissue and blood concentration of NEFA, BHB, as well as BFT and BCS. Together, these studies suggest that the degree of metabolic changes that is caused by overfeeding during the dry period did not produce a proinflammatory response as is observed in obese rodents and humans. A limitation of our study is that we measured the expression of $T N F \alpha$ in subcutaneous adipose tissue only and that expression of this gene might differ from visceral adipose tissue, potentially underestimating an effect of overfeeding and increased lipolysis on adipose tissue inflammation. Two recent studies, however, found expression of $T N F \alpha$ to be greater or equally as large in subcutaneous compared with mesenteric, omental, or retriperitoneal (Saremi et al., 2014), or greater than in both mesenteric and omental adipose tissue ( $\mathrm{Ji}$ et al., 2014b).

\section{CONCLUSIONS}

Cows that were overfed energy during the dry period and exhibited high concentrations of BHB postpartum showed a greater degree of lipogenesis prepartum, whereas there were no differences in lipolytic enzyme activity compared with cows fed a controlled-energy diet prepartum that had low concentrations of BHB postpartum. Baseline insulin concentrations were decreased and NEFA concentrations increased postpartum in the overfed group. No difference existed in the ability to activate AKT phosphorylation following glucose challenge, or in the quantity of insulin receptor, markers of inflammation and PPAR $\gamma$ in adipose tissue between the groups. Expression of adiponectin was increased in the immediate peripartum period in the overfed group. Based on these findings, we conclude that overfeeding energy during the dry period and having high BHB concentrations postpartum does not alter the response to a glucose-induced endogenous insulin stimulus in subcutaneous adipose tissue compared with cows fed a controlled-energy diet and having low BHB concentrations postpartum. Hence, differences in serum concentrations of NEFA between cows overfed energy prepartum and high blood concentrations of
BHB therefore could not be attributed to changes in adipose tissue insulin signaling but may be associated with lower circulating concentrations of glucose and insulin, reflecting a more severe energy deficit in these cows.

\section{ACKNOWLEDGMENTS}

The authors thank Charlene Ryan, Bryant Stuttle (Cornell University, Ithaca, NY), and the staff of the Cornell University Animal Science research facility in Harford, New York. We also greatly acknowledge the help of Mélissa Dupléssis (Université Laval, Québec, Canada) with sample collection. This study was supported by the Agriculture and Food Research Initiative competitive grant no. 2012-67015-30230 from the USDA National Institute of Food and Agriculture (Washington, DC). A. Abuelo was funded by the Pedro Barrié de la Maza Foundation (A Coruña, Spain).

\section{REFERENCES}

Ahmadian, M., J. M. Suh, N. Hah, C. Liddle, A. R. Atkins, M. Downes and R. M. Evans. 2013. PPARgamma signaling and metabolism: The good, the bad and the future. Nat. Med. 19:557-566. http:// dx.doi.org/10.1038/nm.3159.

Akter, S. H., S. Häussler, D. Germeroth, D. von Soosten, S. Danicke, K. H. Sudekum, and H. Sauerwein. 2012. Immunohistochemical characterization of phagocytic immune cell infiltration into different adipose tissue depots of dairy cows during early lactation. J. Dairy Sci. 95:3032-3044. http://dx.doi.org/10.3168/jds.2011-4856.

Astapova, O., and T. Leff. 2012. Adiponectin and PPARgamma: Cooperative and interdependent actions of two key regulators of metabolism. Vitam. Horm. 90:143-162. http://dx.doi.org/10.1016/ B978-0-12-398313-8.00006-3.

Bai, Y., and Q. Sun. 2015. Macrophage recruitment in obese adipose tissue. Obes. Rev. 16:127-136. http://dx.doi.org/10.1111/ obr. 12242 .

Barbour, L. A., C. E. McCurdy, T. L. Hernandez, J. P. Kirwan, P. M. Catalano, and J. E. Friedman. 2007. Cellular mechanisms for insulin resistance in normal pregnancy and gestational diabetes. Diabetes Care 30(Suppl 2):S112-S119. http://dx.doi.org/10.2337/ dc07-s202.

Bauman, D. E., and W. B. Currie. 1980. Partitioning of nutrients during pregnancy and lactation: A review of mechanisms involving homeostasis and homeorhesis. J. Dairy Sci. 63:1514-1529.

Bell, A. W. 1995. Regulation of organic nutrient metabolism during transition from late pregnancy to early lactation. J. Anim. Sci. 73:2804-2819.

Bobe, G., J. W. Young, and D. C. Beitz. 2004. Invited review: Pathology, etiology, prevention, and treatment of fatty liver in dairy cows. J. Dairy Sci. 87:3105-3124. http://dx.doi.org/10.3168/jds. S0022-0302(04)73446-3.

Bonnet, M., L. Bernard, S. Bes, and C. Leroux. 2013. Selection of reference genes for quantitative real-time PCR normalisation in adipose tissue, muscle, liver and mammary gland from ruminants. Animal 7:1344-1353. http://dx.doi.org/10.1017/S1751731113000475.

Bradford, B. J., K. Yuan, J. K. Farney, L. K. Mamedova, and A. J. Carpenter. 2015. Invited review: Inflammation during the transition to lactation: New adventures with an old flame. J. Dairy Sci. 98:6631-6650. http://dx.doi.org/10.3168/jds.2015-9683.

Bradford, M. M. 1976. A rapid and sensitive method for the quantitation of microgram quantities of protein utilizing the principle of protein-dye binding. Anal. Biochem. 72:248-254. 
Capurso, C., and A. Capurso. 2012. From excess adiposity to insulin resistance: The role of free fatty acids. Vascul. Pharmacol. 57:9197. http://dx.doi.org/10.1016/j.vph.2012.05.003.

Cardoso, F. C., W. Sears, S. J. LeBlanc, and J. K. Drackley. 2011. Technical note: Comparison of 3 methods for analyzing areas under the curve for glucose and nonesterified fatty acids concentrations following epinephrine challenge in dairy cows. J. Dairy Sci. 94:6111-6115. http://dx.doi.org/10.3168/jds.2011-4627.

Corl, B. A., S. T. Butler, W. R. Butler, and D. E. Bauman. 2006. Short communication: Regulation of milk fat yield and fatty acid composition by insulin. J. Dairy Sci. 89:4172-4175. http://dx.doi. org/10.3168/jds.S0022-0302(06)72462-6.

Dann, H. M., N. B. Litherland, J. P. Underwood, M. Bionaz, A. D'Angelo, J. W. McFadden, and J. K. Drackley. 2006. Diets during far-off and close-up dry periods affect periparturient metabolism and lactation in multiparous cows. J. Dairy Sci. 89:3563-3577. http://dx.doi.org/10.3168/jds.S0022-0302(06)72396-7.

De Koster, J., W. Van den Broeck, L. Hulpio, E. Claeys, M. Van Eetvelde, K. Hermans, M. Hostens, V. Fievez, and G. Opsomer. 2016. Influence of adipocyte size and adipose depot on the in vitro lipolytic activity and insulin sensitivity of adipose tissue in dairy cows at the end of the dry period. J. Dairy Sci. 99:2319-2328. $10.3168 /$ jds.2015-10440.

De Koster, J. D., and G. Opsomer. 2013. Insulin resistance in dairy cows. Vet. Clin. North Am. Food Anim. Pract. 29:299-322. http:// dx.doi.org/10.1016/j.cvfa.2013.04.002.

Douglas, G. N., T. R. Overton, H. G. Bateman 2nd, H. M. Dann, and J. K. Drackley. 2006. Prepartal plane of nutrition, regardless of dietary energy source, affects periparturient metabolism and dry matter intake in Holstein cows. J. Dairy Sci. 89:2141-2157. http:// dx.doi.org/10.3168/jds.S0022-0302(06)72285-8.

Drackley, J. K., R. L. Wallace, D. Graugnard, J. Vasquez, B. F. Richards, and J. J. Loor. 2014. Visceral adipose tissue mass in nonlactating dairy cows fed diets differing in energy density. J. Dairy Sci. 97:3420-3430. http://dx.doi.org/10.3168/jds.2014-8014.

Edmonson, A. J., I. J. Lean, L. D. Weaver, T. Farver, and G. Webster. 1989. A body condition scoring chart for Holstein dairy cows. J. Dairy Sci. 72:68-78. 10.3168/jds.S0022-0302(89)79081-0.

Elkins, D. A., and D. M. Spurlock. 2009. Phosphorylation of perilipin is associated with indicators of lipolysis in Holstein cows. Horm. Metab. Res. 41:736-740. http://dx.doi.org/10.1055/s-0029-1225359.

Frühbeck, G., L. Mendez-Gimenez, J. A. Fernandez-Formoso, S. Fernandez, and A. Rodriguez. 2014. Regulation of adipocyte lipolysis. Nutr. Res. Rev. 27:63-93. http://dx.doi.org/10.1017/ S095442241400002X.

Garverick, H. A., M. N. Harris, R. Vogel-Bluel, J. D. Sampson, J. Bader, W. R. Lamberson, J. N. Spain, M. C. Lucy, and R. S. Youngquist. 2013. Concentrations of nonesterified fatty acids and glucose in blood of periparturient dairy cows are indicative of pregnancy success at first insemination. J. Dairy Sci. 96:181-188. http://dx.doi.org/10.3168/jds.2012-5619.

Giesy, S. L., B. Yoon, W. B. Currie, J. W. Kim, and Y. R. Boisclair. 2012. Adiponectin deficit during the precarious glucose economy of early lactation in dairy cows. Endocrinology 153:5834-5844. http://dx.doi.org/10.1210/en.2012-1765.

Holtenius, K., S. Agenas, C. Delavaud, and Y. Chilliard. 2003. Effects of feeding intensity during the dry period. 2. Metabolic and hormonal responses. J. Dairy Sci. 86:883-891. http://dx.doi. org/10.3168/jds.S0022-0302(03)73671-6.

Hosseini, A., M. R. Tariq, F. Trindade da Rosa, J. Kesser, Z. Iqbal, O. Mora, H. Sauerwein, J. K. Drackley, E. Trevisi, and J. J. Loor. 2015. Insulin sensitivity in adipose and skeletal muscle tissue of dairy cows in response to dietary energy level and 2,4-thiazolidinedione (TZD). PLoS ONE 10:e0142633 http://dx.doi.org/10.1371/ journal.pone.0142633.

Janovick, N. A., Y. R. Boisclair, and J. K. Drackley. 2011. Prepartum dietary energy intake affects metabolism and health during the periparturient period in primiparous and multiparous Holstein cows. J. Dairy Sci. 94:1385-1400. http://dx.doi.org/10.3168/jds.20103303.
Jaster, E. H., and T. N. Wegner. 1981. Beta-adrenergic receptor involvement in lipolysis of dairy cattle subcutaneous adipose tissue during dry and lactating state. J. Dairy Sci. 64:1655-1663. http:// dx.doi.org/10.3168/jds.S0022-0302(81)82743-9.

Ji, P., J. K. Drackley, M. J. Khan, and J. J. Loor. 2014a. Overfeeding energy upregulates peroxisome proliferator-activated receptor (PPAR)gamma-controlled adipogenic and lipolytic gene networks but does not affect proinflammatory markers in visceral and subcutaneous adipose depots of Holstein cows. J. Dairy Sci. 97:34313440. http://dx.doi.org/10.3168/jds.2013-7295.

Ji, P., J. K. Drackley, M. J. Khan, and J. J. Loor. 2014b. Inflammation- and lipid metabolism-related gene network expression in visceral and subcutaneous adipose depots of Holstein cows. J. Dairy Sci. 97:3441-3448. http://dx.doi.org/10.3168/jds.2013-7296.

Ji, P., J. S. Osorio, J. K. Drackley, and J. J. Loor. 2012. Overfeeding a moderate energy diet prepartum does not impair bovine subcutaneous adipose tissue insulin signal transduction and induces marked changes in peripartal gene network expression. J. Dairy Sci. 95:4333-4351. http://dx.doi.org/10.3168/jds.2011-5079.

Joshi, N. P., and T. H. Herdt. 2009. Clinical Use of Ultrasound for Subcutaneous Fat Thickness Measurements in Dairy Cattle. Pages 150-152 in Current Veterinary Therapy: Food Animal Practice. 5 ed. D. E. Anderson and M. D. Rings, ed. Saunders Elsevier, St. Louis, MO.

Kabara, E., L. M. Sordillo, S. Holcombe, and G. A. Contreras. 2014. Adiponectin links adipose tissue function and monocyte inflammatory responses during bovine metabolic stress. Comp. Immunol. Microbiol. Infect. Dis. 37:49-58. http://dx.doi.org/10.1016/j. cimid.2013.10.007.

Khan, M. J., C. B. Jacometo, D. E. Graugnard, M. N. Correa, E. Schmitt, F. Cardoso, and J. J. Loor. 2014. Overfeeding dairy cattle during late-pregnancy alters hepatic PPARalpha-regulated pathways including hepatokines: Impact on metabolism and peripheral insulin sensitivity. Gene Regul. Syst. Bio. 8:97-111. http://dx.doi. org/10.4137/GRSB.S14116.

Lemor, A., A. Hosseini, H. Sauerwein, and M. Mielenz. 2009. Transition period-related changes in the abundance of the mRNAs of adiponectin and its receptors, of visfatin, and of fatty acid binding receptors in adipose tissue of high-yielding dairy cows. Domest. Anim. Endocrinol. 37:37-44. http://dx.doi.org/10.1016/j. domaniend.2009.01.004.

Locher, L. F., N. Meyer, E. M. Weber, J. Rehage, U. Meyer, S. Danicke, and K. Huber. 2011. Hormone-sensitive lipase protein expression and extent of phosphorylation in subcutaneous and retroperitoneal adipose tissues in the periparturient dairy cow. J. Dairy Sci. 94:4514-4523. http://dx.doi.org/10.3168/jds.2011-4145.

Mann, S., F. A. Leal Yepes, M. Duplessis, J. J. Wakshlag, T. R. Overton, B. P. Cummings, and D. V. Nydam. 2016. Dry period plane of energy: Effects on glucose tolerance in transition dairy cows. J. Dairy Sci. 99:701-717. http://dx.doi.org/10.3168/jds.2015-9908.

Mann, S., F. A. Yepes, T. R. Overton, J. J. Wakshlag, A. L. Lock, C. M. Ryan, and D. V. Nydam. 2015. Dry period plane of energy: Effects on feed intake, energy balance, milk production, and composition in transition dairy cows. J. Dairy Sci. 98:3366-3382. http:// dx.doi.org/10.3168/jds.2014-9024.

McArt, J. A., D. V. Nydam, G. R. Oetzel, T. R. Overton, and P. A. Ospina. 2013. Elevated non-esterified fatty acids and betahydroxybutyrate and their association with transition dairy cow performance. Vet. J. 198:560-570. http://dx.doi.org/10.1016/j. tvjl.2013.08.011.

Mielenz, M., B. Mielenz, S. P. Singh, C. Kopp, J. Heinz, S. Haussler, and H. Sauerwein. 2013. Development, validation, and pilot application of a semiquantitative Western blot analysis and an ELISA for bovine adiponectin. Domest. Anim. Endocrinol. 44:121-130. http://dx.doi.org/10.1016/j.domaniend.2012.10.004.

Ospina, P. A., D. V. Nydam, T. Stokol, and T. R. Overton. 2010. Associations of elevated nonesterified fatty acids and beta-hydroxybutyrate concentrations with early lactation reproductive performance and milk production in transition dairy cattle in the northeastern United States. J. Dairy Sci. 93:1596-1603. http:// dx.doi.org/10.3168/jds.2009-2852. 
Rabelo, E., R. L. Rezende, S. J. Bertics, and R. R. Grummer. 2003 Effects of transition diets varying in dietary energy density on lactation performance and ruminal parameters of dairy cows. J. Dairy Sci. 86:916-925. http://dx.doi.org/10.3168/jds.S00220302(03)73674-1.

Sadri, H., R. M. Bruckmaier, H. R. Rahmani, G. R. Ghorbani, I. Morel, and H. A. van Dorland. 2010. Gene expression of tumour necrosis factor and insulin signalling-related factors in subcutaneous adipose tissue during the dry period and in early lactation in dairy cows. J. Anim. Physiol. Anim. Nutr. (Berl.) 94:e194-e202. http://dx.doi.org/10.1111/j.1439-0396.2010.01005.x.

Saremi, B., S. Winand, P. Friedrichs, A. Kinoshita, J. Rehage, S. Danicke, S. Haussler, G. Breves, M. Mielenz, and H. Sauerwein. 2014. Longitudinal profiling of the tissue-specific expression of genes related with insulin sensitivity in dairy cows during lactation focusing on different fat depots. PLoS ONE 9:e86211 http:// dx.doi.org/10.1371/journal.pone.0086211.

Schröder, U. J., and R. Staufenbiel. 2006. Invited review: Methods to determine body fat reserves in the dairy cow with special regard to ultrasonographic measurement of backfat thickness. J. Dairy Sci. 89:1-14. http://dx.doi.org/10.3168/jds.S0022-0302(06)72064-1.

Selim, S., T. Kokkonen, J. Taponen, A. Vanhatalo, and K. Elo. 2015. Effect of prepartal ad libitum feeding of grass silage on transcriptional adaptations of the liver and subcutaneous adipose tissue in dairy cows during the periparturient period. J. Dairy Sci. 98:55155528. http://dx.doi.org/10.3168/jds.2014-8986.

Selim, S., S. Salin, J. Taponen, A. Vanhatalo, T. Kokkonen, and K. T. Elo. 2014. Prepartal dietary energy alters transcriptional adaptations of the liver and subcutaneous adipose tissue of dairy cows during the transition period. Physiol. Genomics 46:328-337. http://dx.doi.org/10.1152/physiolgenomics.00115.2013.

Singh, S. P. 2014. Characterization of adiponectin at different physiological states in cattle based on an in-house developed immunological assay for bovine adiponectin. PhD diss. Rheinische FriedrichWilhelms-Universität Bonn, Landwirtschaftliche Fakultät, Bonn, Germany.

Sordillo, L. M., and W. Raphael. 2013. Significance of metabolic stress, lipid mobilization, and inflammation on transition cow disorders. Vet. Clin. North Am. Food Anim. Pract. 29:267-278. http://dx.doi.org/10.1016/j.cvfa.2013.03.002.

Yeaman, S. J., G. M. Smith, C. A. Jepson, S. L. Wood, and N. Emmison. 1994. The multifunctional role of hormone-sensitive lipase in lipid metabolism. Adv. Enzyme Regul. 34:355-370.

Zachut, M., H. Honig, S. Striem, Y. Zick, S. Boura-Halfon, and U. Moallem. 2013. Periparturient dairy cows do not exhibit hepatic insulin resistance, yet adipose-specific insulin resistance occurs in cows prone to high weight loss. J. Dairy Sci. 96:5656-5669. http:// dx.doi.org/10.3168/jds.2012-6142. 